\author{
Костенко C. K., \\ аспірант кафбедри правосуддя \\ Київського національного університету ілені Тараса Шевченка,
} член Кваліфікаційно-дисииплінарної колісії прокурорів

\title{
ГЕНЕЗИС ТА СУЧАСНІ ФОРМИ ПРОКУРОРСЬКОГО ВРЯДУВАННЯ В КРАЇНАХ-ЧЛЕНАХ РАДИ ЄВРОПИ
}

\begin{abstract}
Анотація: Стаття присвячена 3'ясуванню генезису такого органу прокурорського врядування, як Кваліфікаційно-дисциплінарна комісія прокурорів, через виявлення та з'ясування діалектики розвитку аналогічних за своїми функціями організацій в країнах-членах Ради Європи. За результатами проведеного дослідження з'ясовано, що генезис у вітчизняній правовій системі вказаного інституту можна прослідкувати від аналогічних за своєю правовою природою державних інститутів, які з'явились вперше 1883 року у Франції (Вища рада магістратури) для адміністрування органів судової влади, а потім поширились у більшості країн Свропи, зазнавши під час свого становлення у сучасних формах суттєвої модифікації на національному підгрунті. Ці інститути розповсюдили свою юрисдикцію не тільки на суддів, а згодом і на прокурорів, оскільки останні вважаються представниками системи правосуддя.

Ключові слова: Рада Європи, національна правова система, судова влада, система правосуддя, вищі судові ради, Кваліфікаційно-дисциплінарна комісія прокурорів.
\end{abstract}

Постановка проблеми. В історії вітчизняної прокуратури немає інститутів, які можна було б вважати прототипами органів прокурорського самоврядування та такого органу прокурорського врядування, як Кваліфікаційно-дисциплінарна комісія прокурорів (далі - Комісія). В той же час для характеристики правового статусу Комісії, дослідження іï генезису потрібно з'ясувати, наскільки повно та якісно був врахований вітчизняним законодавцем досвід зарубіжних країн, з якого був запозичений цей державний інститут.

Мета статті - прослідкувати генезис нового державного органу - Комісії через виявлення та з'ясування діалектики розвитку аналогічних за своїми функціями організацій в країнах-членах Ради Європи. При цьому маються на увазі державні інститути, які, виконуючи схожі з Комісією функції, мають подібні організаційно-правові характеристики порядку їх утворення та здійснення повноважень.

Виклад основного матеріалу дослідження. Епоха просвітництва та буржуазні революції в Європі XVIII-XIX сторіччя мали однією з ідейних основ прагнення до зламу феодальних інститутів одноосібної влади та свавілля. Таке прагнення втілилося у впровадженні принципу розподілу державної влади, відповідно до якого судова влада є окремою гілкою державної влади. Ця ідея відображена в роботах видатного французького філософа Ш. Монтеск'є. Саме з судовою гілкою влади пов'язані сподівання громадян на рівність перед законом та справедливість. Однак такі сподівання з часом виявлялись марними, оскільки політичні еліти, які перебували при владі, намагались i надалі використовувати суди та прокуратуру для боротьби
3 опонентами та протиправного утримання влади. Подальший прогрес західних ліберальних демократій пов'язаний, зокрема, зі створенням та укріпленням інститутів, які забезпечують незалежність судової влади. В цьому ж напряму рухається і вітчизняна правова система, в якій зроблена спроба рецепіювати західноєвропейські самоврядні інститути адміністрування судової влади та системи правосуддя в цілому.

Деяким аспектам діяльності Комісії та її аналогів за кордоном присвятили свої праці такі вчені, як І.О. Артеменко, А.П. Горзов, О.О. Долгий, В.В. Долежан, Л.С. Дрогомирецька, П.М. Каркач, І.М. Козьяков, М.В. Косюта, О.М. Літвак, I.Є. Марочкін, О.Р. Михайленко, А.М. Мудров, Н.С. Наулік, С.В. Подкопаєв, Ю.С. Полянський, Н.О. Рибалка, М.В. Руденко, О.Ф. Скакун, О.М. Толочко та інші.

Усвідомлюючи дивергентність національних правових систем як фактор ускладнення їх порівняльного аналізу, нами в якості відправної точки дослідження висунута гіпотеза про те, що характеристику генезису інститутів прокурорського врядування в різних країнах-членах Ради Європи можна пов' язати з типологію правових сімей, які за визначенням є сукупністю правових систем, об'єднаних спільністю історичного формування, структури права, його джерел, провідних галузей та інститутів, правозастосування, правосвідомості, поняттєвого апарату юридичної науки [1]. Вчення про правові сім’ї пов'язано насамперед 3 ім'ям ще одного видатного французького вченого - Рене Давида, який висунув ідею трихотомії - виділення трьох правових сімей: соціалістичної, англосаксонської та романо-германської, до яких примикає іншій юридичний світ, який охоплює чотири п'ятих планети під назвою «релігійні та традиційні системи» [2]. Суттєве значення для нашого аналізу має розрізнення германської та романської частини правової сім’”. Звісно, віднесення країн Європи до германських або романських правових систем дуже умовне, оскільки взаємна конвергенція цих систем $\epsilon$ доволі глибокою. Власне, їх розрізнення в науці насамперед пов' язується з інституційним або пандектним принципом побудови нормативно-правових актів, а не державним апаратом.

Отже, з поля наукового пошуку, завдяки нашій гіпотезі, можна одразу виключити країни соціалістичної та англосаксонської правих сімей. Перші - завдяки тому, що таких країн-членів Ради Європи не існує, другі - через те, що в цих країнах, до яких належать Великобританія, Ірландія та Мальта, не існує прокуратури в тому розумінні державного органу, яке $€$ принциповим для характеристики органів прокуратури континентальної Європи, в тому числі України як єдиної централізованої системи [3].

Германські правові системи слід почати досліджувати з Німеччини, в прокуратурі якої, як ми побачимо, відсутні будь- 
які організації, які можна було віднести до самоврядних як на федеральному, так і на місцевому рівні, хоча $є$ потужне так зване суддівське представництво, яке суттєво відрізняється від вітчизняного суддівського самоврядування та врядування, проте також є інституціональною гарантією незалежності суддів.

Інститут прокуратури в його сьогоднішній формі в Німеччині є порівняно молодим. В 1798 році Франція вперше ввела орган звинувачення на тодішніх окупованих лівобережних рейнських територіях. Пізніше це запозичили деякі інші німецькі землі, зазнаючи впливу правових інститутів Франції в ході Наполеонівських війн. У 1879 році, коли вступили в силу закони про юстицію Рейху, була введена прокуратура на всій території Німецької держави. До цього часу суди могли здійснювати розслідування та виносити рішення. Тогочасний безлад, пов'язаний з цим правовим станом, був відтворений в народному прислів 'і: «Тому, у кого обвинувач є суддею, потрібен Бог за адвоката». Сьогодні прокуратура повинна діяти як «сторож закону». Саме вона повинна, «діючи при поліції та судах як сторож закону, формувати посередницькі узи між ними». Із введенням прокуратури було пов'язане передусім очікування, що кримінальне провадження буде відбуватись особливим чином в рамках праводержавності та справедливості.

При Федеральному Верховному Суді ФРН в м. Карлсруе діє Федеральна Генеральна прокуратура, яка підпорядкована Федеральному міністру юстиції, проте генеральні прокуратури земель не перебувають в ієрархічному підпорядкуванні вищевказаної прокуратури, а підпорядковуються відповідному міністру юстиції землі. Відносно прокурорів діють загальні принципи і норми права про статус чиновників. Прокуратури побудовані ієрархічно і монократично. Генеральні прокурори керують установою: іiі співробітники діють при здійсненні службових обов'язків як їхні представники. Генеральний прокурор підлягає службовому нагляду з боку відповідного міністра юстиції, який несе перед відповідним парламентом політичну відповідальність за діяльність прокуратури.

Принципових особливостей правової системи ФРН, якими 6 пояснювався такий стан законодавчого врегулювання статусу прокуратури та прокурорів не існує, тому німецькі фахівці зазначають, що в країні слід надалі наполегливо працювати над тим, щоб визначити прокуратуру такою ж самою незалежною як і суди, адже ще в XIX столітті німецький громадянський рух за свободу вимагав незалежної прокуратури в якості «судді в досудовому провадженні». В європейському порівнянні нормативне врегулювання службового становища прокурора, тобто норми службового права прокурорів в Німеччині, є одним 3 найгірших [4].

Рада Європи зазначає, що у випадку залежної від виконавчої влади прокуратури повинно бути нормативно забезпечено, щоб прокуратура була в змозі здійснювати кримінальне переслідування без тиску з боку державних чиновників за вчинені ними злочини, як-то: корупцію, зловживання владою, серйозні порушення прав людини й інші злочини, визнані міжнародним правом [5]. Не можна говорити про те, що ця вимога повністю виконана в німецькому законодавстві. Цьому протистоїть так зване зовнішне, тобто не по конкретній справі та по конкретним діям, право міністра юстиції давати вказівки. Хоча на практиці факти неправомірного втручання в діяльність прокурорів не відомі.

Добір прокурорів та суддів у Німеччині уніфікований та здійснюється спеціальними комісіями при вищих судах.
У разі позитивного рішення комісії прокурор приймається на роботу на випробувальний термін 3 роки. Це рішення формально не є обов'язковим для Міністра юстиції щодо призначення особи прокурором на випробувальний термін, проте на практиці відмов не відбувається. Закон проголошує, що прокурором може бути призначений тільки той, хто має здатність обіймати посаду судді. В той же час, на відміну від судді, прокурора можна перевести на іншу посаду без його згоди, оскільки він $€$ чиновником.

У дисциплінарних провадженнях по справах прокурорів рішення приймають дисциплінарні суди у справах суддів. Щодо прокурорів на службі Федерації в якості дисциплінарного суду діє спеціальний сенат у Федеральному Верховному суді, в землях утворюються окремі дисциплінарні суди [6]. Крім того, діє система оцінювання прокурорів за докладно розробленими критеріями. При вирішенні питань кар'єрного просування та періодично (раз на чотири роки) оцінювання проводиться визначеними законодавством службовими начальниками прокурора.

3 самого початку прокуратура Німеччини була і залишається підпорядкована Міністерству юстиції, а не Міністерству внутрішніх справ, а отже, Міністерству поліції, для того, щоб репрезентувати «правову, а не силову волю держави». Для того щоб відповідати цим вимогам, згідно з судовою практикою Федерального конституційного суду та Федерального Верховного Суду, а також згідно з власним уявленням прокуратура, $€$ по відношенню до суду самостійним органом кримінальної юстиції, який спільно з судом повинен здійснювати повноваження щодо гарантування правосуддя [7].

Хоча прокурори не $є$ частиною судової влади в світлі Основного Закону [8] (ст. 92), але, виходячи із своїх спеціальних повноважень в судовому процесі, прокуратура не може бути віднесена і до виконавчої влади. Будучи органом державного кримінального переслідування, який пов'язаний законом і зобов'язаний, так само як і суд, направляти свої дії на встановлення істини та віднаходження справедливого вироку, прокуратура підпорядкована системі правосуддя.

На наш погляд, така концепція мала фундаментальний вплив на вітчизняне законодавство у цій галузі, хоча траєкторія руху була зворотною: спочатку не суди брали на себе функцію прокуратури, а навпаки - прокуратура була вищою за суд. Сьогодні згідно з Конституцією України [9] прокуратура не є органом судової влади, проте віднесена до системи правосуддя. На відміну від такої концепції, для романських правових систем, у яких, як буде видно нижче, нами запозичені інститути самоврядування та врядування в системі правосуддя, характерним $€$ визначення прокурорів в якості магістратів, тобто представників саме судової влади.

Можна констатувати, проте 3 великими виключеннями, що для країн, які відносяться до германської підгрупи, більш характерна відсутність органів, які подібні Комісії. Наприклад, такі країни Прибалтики, як Литва та Латвія, не мають інститутів прокурорського самоврядування, в них генеральними прокурорами створюються лише ради, які є дорадчими органами. В той же час в Естонії існує Генеральна асамблея прокурорів, тобто зібрання всіх прокурорів, яке скликається не рідше, ніж раз на рік та обирає більшість членів Комісії по добору та оцінці прокурорів, Дисциплінарної комісії, затверджує кодекс етики тощо. 
До країн цієї групи також можна віднести Австрію, Чехію, Словакію, Угорщину, Люксембург. Хоча в Чехії органи прокурорського самоврядування не існують, в Законі про прокуратуру [10] закріплено, що Спілка прокурорів Чеської республіки є добровільним неполітичним об'єднанням прокурорів та помічників прокурорів. Згідно зі Статутом цього об’єднання воно має ціллю поступове впровадження самоврядних елементів в системі прокуратури. В Угорщині діє Національна асоціація прокурорів.

Для організації органів прокуратури таких країн, як Росія, Арменія та Азербайджан, характерний суттевий спадок соціалістичної системи: жорстка централізованість, залежність від правлячої еліти та відсутність реального відмежування від виконавчої влади. Тому закономірно, що в цих країнах немає подібних інститутів самоорганізації прокурорів та функціональна незалежність прокурорів викликає великі сумніви.

Для скандинавських країн (Норвегія, Швеція, Фінляндія, Ісландія та Данія) також характерна відсутність аналогів Комісії, зокрема, через суттєву специфіку їх правових систем, які за визначенням деяких дослідників багато в чому є автентичними. Наприклад, в Данії немає відмінностей між адвокатами та іншими практикуючими юристами, які характерні для інших країн, тому в Законі про судову владу [11] статус всіх юристів регулюється однією статтею (119). Датське юридичне товариство складається зі всіх датських юристів, яких призначає або рекомендує на відповідні посади, в тому числі в прокуратурі, Міністр юстиції (який також є генеральним прокурором). Членство у цьому товаристві для юристів $€$ обов'язковим, оскільки саме органи цього товариства здійснюють дисциплінарні процедури щодо юристів, представляють юридичний корпус країни у взаєминах з іншими державними та міжнародними органами.

Характеристику романських правових систем справедливо почати 3 Франції, оскільки Вища рада магістратури Франції (далі - ВРМ Франціі) утворена в 1883 році та $€$ найдавнішим подібним органом у світі, а Франція по праву вважається родоначальницею інституту вищих судових рад та похідних від нього моделей адміністрування органів системи правосуддя.

За період свого існування статус вказаного органу неодноразово зазнавав суттевих змін, проте загальний напрям його реформування полягав у зміцненні його незалежності. Модифікації ВРМ Франції 1883, 1946 та частково 1958 року стосувались тільки суддів. Припускалось навіть підпорядкування прокуратури Міністерству внутрішніх справ. Закон 1958 року встановив унітарне управління прокуратурою та Рада не мала юрисдикції по відношенню до прокурорів. Вони залишились в управлінні безпосередньо міністра юстиції.

Поступово картина змінювалась завдяки насамперед судовій практиці Конституційної ради (конституційний суд) на користь приєднання прокуратури до судової влади, а також роботі Консультативного комітету по змінах до Конституції Франції під головуванням відомого французького юриста Ж. Веделя, яким в 1993 були представлені законопроекти щодо конституційних змін, серед яких пропонувалась значна реформа правового статусу ВРМ. Консультативна рада прокурорів Франції також підтримала приєднання прокуратури до судової влади. Таким чином, після прийняття конституційного закону 1994 року ВРМ Франції наділена компетенцією щодо всіх магістратів із створенням окремих складів Ради для суддів та для прокурорів, а компетенцією щодо забезпечення єдності цих складів наділений іiі пленарний склад. Проте ВРМ Франції вносила лише пропозиції міністру юстиції щодо призначення прокурорів та не мала повноважень впливати на призначення Радою міністрів (уряд) генеральних прокурорів в апеляційних судах та генерального прокурора при касаційному суді.

Визначною новелою конституційної реформи, впровадженої в 2008 році, стало надання для затвердження Ради міністрів пропозицій ВРМ про призначення генеральних прокурорів. Останні три Міністра юстиції Франції також взяли на себе зобов'язання систематично слідувати рекомендаціям ВРМ Франції, які стосуються призначень та притягнення прокурорів до дисциплінарної відповідальності, та де-факто жодного разу не давалось негативних висновків щодо призначення прокурорів з 2008 року, що фактично призвело до однакової практики 3 формування корпусу всіх магістратів.

Згідно з Конституцією Франції [12] (ст. 65) головою ВРМ $€$ Президент Республіки. Саме він $€$ одночасно гарантом незалежності судової влади. Міністр юстиції є віце-головою та заміщує Президента у разі необхідності. Склад Ради, повноважений у відношенні прокурорів, включає, окрім Президента Республіки та міністра юстиції, п'ять прокурорів та одного суддю, а також члена Державної ради (дорадчий орган французького уряду та вищий адміністративний суд Французької республіки) та трьох осіб, які не мають відношення ані до парламенту, ані до судової системи та призначаються, відповідно, Президентом Республіки, головою Національного зібрання (нижня палата парламенту) та головою Сенату (верхня палата парламенту).

Склад ВРМ Франції, повноважений у відношенні прокурорів, дає свій висновок по призначенням та дисциплінарним стягненням щодо прокурорів (в останньому випадку в ньому головує Генеральний прокурор при Касаційному суді). На відміну від суддів, рішення Ради про дисциплінарне стягнення щодо прокурора не має юрисдикційного характеру, а у вигляді рекомендації надається міністру юстиції. Рішення останнього у разі перевищення повноважень може бути оскаржено у Державній раді.

Конституційна реформа 2008 року надала право прямого звернення до ВРМ Франції сторін судового провадження у разі, коли вони вважають, що магістратом вчинений дисциплінарний проступок при виконанні його функцій.

Пленарний склад ВРМ Франції на своєму засіданні приймає рішення стосовно етики магістратів, а також з будь-яких питань, які стосуються функціонування судової влади, які передає міністру юстиції. Рада складає та публікує кодекс етичної поведінки магістратів. В 2016 році вона створила службу з етики, до якої може звернутися будь-який магістрат 3 питаннями деонтологічного характеру, які стосуються його особисто.

Нова спроба реформи ВРМ Франції, яка була розпочата в 2013 році, не вдалась. Хоча первинний текст законопроекту передбачав реформу складу Ради, відповідно до якої кваліфіковану більшість в ньому повинні складати магістрати, які обрані своїми колегами, а також їй повністю передавались повноваження 3 вирішення питань незалежності судових органів та етики суддів, поки що в парламенті мають шанси на успіх лише правки щодо самостійного призначення прокурорів та повна передача щодо них дисциплінарної влади до ВРМ [13].

В той же час, інститут вищих судових рад, напевне, не випадково має в наукових колах Європи назву Франко-італій- 
ської моделі, оскільки саме італійське законодавче регулювання статусу Вищої ради магістратури, на наш погляд, більш повно забезпечує незалежність судової влади.

Відповідно до Конституції Італії [14] (ст. 104) магістратура представляє собою автономну та незалежну від всякої іншої влади корпорацію (спільноту). Власне, відповідний розділ Конституції, який регулює питання організації судової влади та судоустрою, має назву «Магістратура». Закріплено, що магістрати розрізняються між собою тільки за своїми функціями, тобто безпосередньо на конституційному рівні статус прокурорів прирівняний до статусу суддів.

Вищим конституційним органом в судовій ієрархії є Вища рада магістратури (далі - ВРМ Італіі), яка в сучасному статусі запрацювала в 1959 році (у цього органу були попередники). В ній головує Президент Республіки, проте Італія, на відміну від Франції, є парламентською республікою, тому можливості Президента 3 політичного впливу на Раду обмежені. Перший голова та Генеральний прокурор Касаційного суду «по праву» входять до Ради. Дві третини інших членів (16) обираються всіма штатними суддями 3 числа осіб, які належать до різних категорій магістратури (тобто обраними можуть бути і магістрати, які виконують функції прокурорів), а одна третина (8) - парламентом на спільному засіданні палат з числа штатних професорів права університетів та адвокатів 3 15-річним стажем

Таким чином, кваліфікована більшість в ВРМ Італії належить представникам судової влади, які обрані своїми колегами, а всі інші члени (крім Президента) є авторитетними юристами.

Компетенція ВРМ Італії щодо магістратів є майже монопольною, оскільки вона вирішує всі питання їх кар'єри: прийом до складу магістратури, стажування; переводи, підвищення, призначення на керівні посади; професійне оцінювання; відставки та звільнення; накладення дисциплінарних стягнень та інші питання, пов'язані зі статусом магістратів. Крім того, ВРМ здійснює призначення та відкликання почесних віце-преторів, мирових суддів і їх заступників, а також членів спеціалізованих відділень, які не є магістратами. Єдиним випадком, коли міністр юстиції має певне відношення до призначень, є надання ним свого висновку щодо магістрату, який призначається на керівну посаду. Цей висновок не обов'язковий для врахування Радою, проте така практика вважається виправданою, оскільки за Конституцією цей міністр відповідальний за організацію та функціонування служб, пов'язаних 3 правосуддям [15].

Наразі можна назвати наступні державні органи в європейських країнах, які рецепіювали Франко-італійську модель вищих судових рад, функції яких стосуються і суддів, і прокурорів: Вища ради магістратури Румунії, Вища рада юстиції Бельгії, Вища судова рада Болгарії. До цієї ж групи, щоправда доволі умовно через значну національну специфіку, можна віднести Вищу судову раду по цивільному та кримінальному правосуддю Греції, Вищу раду суддів та прокурорів Туреччини.

Генеральна рада юстиції Іспанії створена згідно з Конституцією 1978 року відповідно до зразків інших сусідніх країн, таких як Франція, Португалія i, особливо, Італія. Це стало абсолютною новелою, оскільки в історії країни не існувало якого-небудь подібного попередника, тобто автономного державного органу адміністрування судової влади та гаранта іiі незалежності [16]. За статусом прокурори в Іспанії прирівняні до суддів, проте до «португальського впливу» на іспанську модель, на наш погляд, слід віднести відсутність у Генеральної ради юстиції повноважень щодо прокурорів. В прокуратурі створюється окремо Рада прокурорів, яка має дисциплінарну владу над прокурорами та інші повноваження. В Португалії функціонує Вища рада прокурорів.

Також до цієї групи країн, в яких створені окремі самоврядні органи адміністрування прокуратури, можна віднести Вищу прокурорську раду Албанії, Національну раду прокуратури Польщі, Державну прокурорську раду в Сербіі, Хорватії та Словенії, Вищу раду прокурорів Молдови, Прокурорську раду Грузії, а також, знов таки умовно через суттєву специфіку порядку створення, - Раду генеральних прокурорів Нідерландів. Саме до цієї групи країн належить і Україна.

Висновки. Генезис у вітчизняній правовій системі такого нового інституту, як Комісія, можна прослідкувати від аналогічних за своєю правовою природою інститутів, які з'явились вперше у Франції для адміністрування органів судової влади, а потім поширились у більшості країн Європи, зазнавши суттєвої модифікації на національному підгрунті. Ці інститути згодом розповсюдили свою юрисдикцію не тільки на суддів, а і на прокурорів, оскільки останні вважаються представниками системи правосуддя.

Узагальнюючи дані щодо органів прокурорського самоврядування та врядування країн-членів Ради Європи, можна зробити наступні висновки.

По-перше, для цих країн є характерним визначення статусу прокурорів нарівні зі статусом суддів, що, зокрема, має наслідком передачу кадрових та юрисдикційних повноважень щодо прокурорів до незалежних органів врядування в системі правосуддя, які є або спільними для прокурорів і суддів, або створюються для прокурорів окремо. Однак в Україні законодавчий статус прокурорів не прирівняний до суддівського.

По-друге, навіть за наявності спільного органу врядування у суддів та прокурорів в його структурі виокремлюються суддівські та прокурорські підрозділи. За наявності окремих органів їх компетенція не пересікається. В той же час в Україні рішення про притягнення прокурорів до дисциплінарної відповідальності можуть бути переглянуті Вищою радою правосуддя. Цей же орган наділений компетенцією щодо ухвалення рішень про порушення прокурорами вимог щодо несумісності.

По-третє, за наявності окремого органу прокурорського врядування він $€$ консолідованим, на відміну від вітчизняної моделі, де суттєві питання прокурорської кар'єри віднесені до компетенції відмінних від органів прокурорського врядування суб'єктів адміністрування системи прокуратури, в тому числі Ради прокурорів України. Комісія та Рада організаційно та функціонально є окремими органами.

По-четверте, зазвичай до складу подібних органів за посадою входить генеральний (головний) прокурор. Строк повноважень членів такого органу становить 4-5 років без права повторного переобрання. В той же час до складу Комісії можуть входити тільки рядові прокурори, строк повноважень яких складає 3 роки.

По-п'яте, до повноважень органів прокурорського врядування за кордоном зазвичай належить: участь у вирішенні питань про призначення генерального прокурора та призначення прокурорів на адміністративні посади; добір та переведення прокурорів; вирішення питань про дисциплінарну відповідальність; професійне оцінювання; відставки та звільнення 
прокурорів. Однак Комісія та Рада прокурорів України не здійснюють ніяких повноважень при призначенні Генерального прокурора. Призначення на більшість адміністративних посад в системі прокуратури відбувається одноосібними рішеннями прокурорів, які займають адміністративні посади. Щодо призначення та звільнення з деяких адміністративних посад Рада вносить лише рекомендації Генеральному прокурору. Системи оцінювання прокурорів в Україні взагалі не створено.

По-шосте, організаційно-правові механізми формування органів прокурорського врядування передбачають обрання до їх складу прокурорів прокурорами. При цьому зазвичай передбачена можливість часткового формування складу такого органу не органами прокурорського самоврядування, проте прокурори, обрані прокурорами, мають становити більшість у його складі. В складі Комісії з 11 членів лише 5 є прокурорами, які обираються прокурорами.

На нашу думку, під час подальшого реформування прокуратури України та удосконалення правового статусу Комісії мають бути враховані зазначені висновки з досвіду європейських країн.

\section{Jimepamypa:}

1. Порівняльне правознавство: Підручник для студентів юридичних спеціальностей вищих навчальних закладів / В.Д. Ткаченко, С.П. Погребняк, Д.В. Лук'янов. Х.: Право, 2003. 274 с.

2. Давид Р., Жоффре-Спинози К. Основные правовые системы современности: Пер. с фр. В.А. Туманова. М.: Междунар. отношения, 1996. $400 \mathrm{c}$.

3. Заворотний Я.С. Аналоги органів прокуратури у Великобританії, Ірландії та на Мальті. Актуальні проблеми політики. Вип. 37. Одеса: Фенікс, 2009. С. 128-137.

4. Матеріали, надані Німецьким Фондом міжнародного правового співробітництва 11.07.2017 під час робочої зустрічі з членами Кваліфікаційно-дисциплінарної комісії прокурорів в Національній академії прокуратури України. Київ. 2017.

5. Рекомендація Rec (2000) 19 Комітету Міністрів Ради Європи державам-членам щодо ролі прокуратури в системі кримінального правосуддя, п. 16. URL: https://supreme.court.gov.ua/userfiles/ Rec_2000_19_2000_10_6.pdf. Дата звернення 05.10.2018.

6. Німецький закон про суддів / Законодавство про судовий устрій та статус суддів в Німеччині. Збірник матеріалів, виданих Німецьким Фондом міжнародного правового співробітництва. Київ, 2015. C. 177.

7. Зельтер Вальтер. Особливості правового статусу прокуратури Федеративної Республіки Німеччина в системі органів державної влади / Прокуратура України в умовах європейської інтеграції: матеріали Міжнародної науково-практичної конференції (19 травня 2016 року). - К.: Національна академія прокуратури України, 2016. - 334 c. URL: http://napu.com.ua/wp-content/uploads/pdf/ Materialy_Conferencii(1).pdf. Дата звернення 06.10.2018.

8. Конституция Федеративной Республики Германия URL: https://legalns.com/download/books/cons/germany.pdf. Дата звернення 05.10.2018.

9. Конституція України. Відомості Верховної Ради, 1996, № 30, ст. 131.

10. Закон про прокуратуру Чеської Республіки. URL: https:// www.podnikatel.cz/zakony/zakon-o-statnim-zastupitelstvi/uplne/\# cast6. Дата звернення 06.10.2018.

11. Закон про судову владу Данії. URL: https://www.retsinformation.dk/ forms/R0710. aspx?id=183537\#id5d53cbd4-5891-40c2-b185c6e $52 \mathrm{~d} 815 \mathrm{cc} 9$.
12. Конституция Франции. URL: https://worldconstitutions.ru/?p=138\& page $=2$. Дата звернення 06.10.2018.

13. Офіційний веб-сайт Вищої ради магістратури Франції. URL: http://www.conseil-superieur-magistrature.fr/le-csm/histoire-etpatrimoine. Дата звернення 06.10.2018.

14. Конституция Италии. URL: https://legalns.com/download/books/ cons/italy.pdf. Дата звернення 06.10.2018.

15. Офіційний веб-сайт Вищої ради магістратури Італії. URL: https:// www.csm.it/web/csm-internet/home. Дата звернення 06.10.2018.

16. Офіційний веб-сайт Генеральної ради юстиції Iспанії. URL: http://www.poderjudicial.es/portal/site/cgpj/menuitem.96dc62a619 $366 \mathrm{a} 2141 \mathrm{a} 25 \mathrm{f} 82 \mathrm{dc} 432 \mathrm{ea} 0 /$ ? vgnextoid=3a20f20408619210 $\mathrm{VgnVC}$ M100000cb34e20aRCRD\&vgnextlocale=en\&vgnextfmt=default\&la ng_choosen=en. Дата звернення 07.10.2018.

Костенко С. К. Генезис и современные формы прокурорского управления в странах-членах Совета Европы

Аннотация. Статья посвящена выяснению генезиса такого органа прокурорского управления, как Квалификационно-дисциплинарная комиссия прокуроров, путем обнаружения и выяснения диалектики развития аналогичных по своим функциям организаций в странах-членах Совета Европы. По результатам проведенного исследования установлено, что генезис в отечественной правовой системе указанного института можно проследить от аналогичных по своей правовой природе государственных институтов, возникших впервые в 1883 году во Франции (Высший совет магистратуры) для администрирования органов судебной власти, которые затем распространились в большинстве стран Европы, претерпев во время своего становления в современных формах существенную модификацию на национальной почве. Эти институты распространили свою юрисдикцию не только на судей, а впоследствии и на прокуроров, поскольку последние считаются представителями системы правосудия.

Ключевые слова: Совет Европы, национальная правовая система, судебная власть, система правосудия, высшие судебные советы, Квалификационно-дисциплинарная комиссия прокуроров.

Kostenko S. Genesis and modern forms of the Public Prosecutor's governance in the Council of Europe member countries

Summary. There are no institutes that could be regarded as prototypes of the Qualification and disciplinary commission of public prosecutors in the history of local prosecution. Thus, the purpose of this article is to track the genesis of the Commission through the detection of its analogues and to analyze the dialectics of their development abroad. As a result of the research it is defined that the genesis of such institute as Commission in the domestic legal system can be tracked to the similar legal institutes that were created in France in 1883 for the first time (High Magistrate Council) for the administration of the bodies of the judicial branch. Later the said institutes became popular in most of European countries being significantly modified on each national level. Under the jurisdiction of these institutes were not only judges but also the prosecutors as the prosecutors are the representatives of the Justice system.

Key words: Council of Europe, national legal system, judiciary, justice system, supreme court councils, Qualifications and Disciplinary Commission of Public Prosecutors. 